\title{
高速移動内圧を受ける円管の動的挙動
}

\author{
永 井 光 輝 ${ }^{*}$ 臺丸谷 政 志** 小 林 秀 敏***
}

\section{Dynamic Behavior of Circular Tube Subjected to High-Rate Moving Internal Pressure}

by

\author{
Koki NAGAI ${ }^{*}$, Masashi DaImaruya ${ }^{* *}$ and Hidetoshi KobaYASHI ${ }^{* * *}$
}

\begin{abstract}
The dynamic behavior of a circular tube subjected to high-rate moving internal pressure was examined experimentally and analyzed numerically with FEM code, LS-DYNA. The time histories of transient stress waves in both the circumferential and axial directions were observed from strain gauges pasted on the outer surface of several positions along the circular tube with a constant cross-section. Also, the time histories of high-rate moving internal pressures were measured by piezoelectric elements embedded in the inner surface layer of the circular tube. The moving internal pressure for the load conditions of the numerical analysis was based on the experimental observation and the analysis was carried out under the condition of two-dimensional model in the cylindrical coordinates. The numerical results showed comparatively good agreement with the experimental ones and the analytical model proposed in this study is effective. Additionally, the dynamic behavior of inner and outer surface of the circular tube was predicted.
\end{abstract}

Key words : Dynamic behavior, High-rate moving internal pressure, Circular tube, Transient stress, Radial displacement, FEM

\section{1 緒言}

近年，二段式軽ガス銃の様な高速，超高速で飛翔体を 発射する設備が普及 ${ }^{1)}$ し，高エネルギー速度加工 ${ }^{2)}$ 超高 圧領域の構成方程式や宇宙空間でのデブリ衝突問題 ${ }^{3)}$ 等 の研究に使用されており，これらの研究において，飛翔 体をより精密（正確な速度，正確な飛翔体姿勢）に，よ り高速に発射することへの要求が高まってきている。こ のことは，飛翔体の起動から発射に至る発射円筒の挙動， つまり移動内圧を受ける円管の動的挙動を明らかにする ことの重要性を示していると考えられる。

移動内圧を受ける円管の動的挙動問題については, 1960 年代から理論的な研究 4$)$ 6) が行われてきた。近年 に扣いても内圧の移動速度が円管の限界速度に達する際 の共振現象についての研究7) -9) が行われているが，今ま での研究の多くは, 内圧の移動速度が一定であるとの仮 定により行われているものであり，加速中の移動内圧下 の研究例は数少ない. また, 軍事的研究の背景もあり, 研究の多くは詳細が明らかにされてこなかった。

本研究では, 加速中の高速移動内圧を受ける円管の動 的挙動を解明するため，一様断面の円管内で無煙火薬を 発火させ，飛翔体を発射することにより円管内面に高速 移動内圧を負荷する実験を行った. 円管の数力所で，外 面に貼付したひずタゲージにより円管の円周方向および 軸方向の応力波形を，円管内面に設置した圧力センサに より円管内の圧力波形を計測した。また，実験により得
られた移動内圧から荷重条件を決定し，動的 FEM 解析 コードである LS-DYNAを用いた数值解析を行い，円管 内外面の半径方向変位挙動を推測した.

\section{2 実験}

\section{$2 \cdot 1$ 試験体}

二段式軽ガス銃の発射円筒には，ニッケルクロムモリ ブデン鋼等が用いられる ${ }^{10)}$ が，本研究で用いた円管には， 比較的入手し易く，ニッケルクロムモリブデン鋼と同等 の強度を有するクロムモリブデン鋼 SCM440-H (JIS G 4105）を用いた，使用材料の機械的性質を把握するた め，万能試験機（INSTRON 5586）を用いて静的引張試 験を行った。得られたクロムモリブデン鋼の機械的性質 をTable I に示す。なお， $\mathrm{c}_{0}$ は 1 次元縦弾性波の伝ぱ速 度で, $\mathrm{c}_{0}=\sqrt{(\mathrm{E} / \rho)}$ により求めた值である.

Table I . Mechanical properties of the material (SCM440-H).

\begin{tabular}{c|c}
\hline Property & Value \\
\hline Young's modulus, $\mathrm{E}$ & $210[\mathrm{GPa}]$ \\
Poisson's ratio, $v$ & 0.3 \\
Yield strength, $\sigma_{\mathrm{Y}}$ & $634[\mathrm{MPa}]$ \\
Tensile strength, $\sigma_{\mathrm{t}}$ & $829[\mathrm{MPa}]$ \\
Elongation, $\delta$ & $13.5[\%]$ \\
Density, $\rho$ & $7790\left[\mathrm{~kg} / \mathrm{m}^{3}\right]$ \\
Bar velocity, $\mathrm{c}_{0}$ & $5192[\mathrm{~m} / \mathrm{s}]$ \\
\hline
\end{tabular}

* 住友重機械工業(株) $=188-8585$ 西東京市谷戸町, Sumitomo Heavy Industries, Ltd., Yato-cho, Nishi-tokyo, $188-8585$

** 正 会 員 室蘭工業大学工学部機械システム工学科 T050-8585 室蘭市水元町, Dept. of Mech. Systems Eng., Muroran Inst. of Tech., Mizumoto-cho, Muroran, 050-8585

*** 正 会 員 大阪大学大学院基礎工学研究科 $=560-8531$ 豊中市待兼山町, Graduate School of Eng. Sci., Osaka Univ., Machikaneyama-cho, Toyonaka, 560-8531 


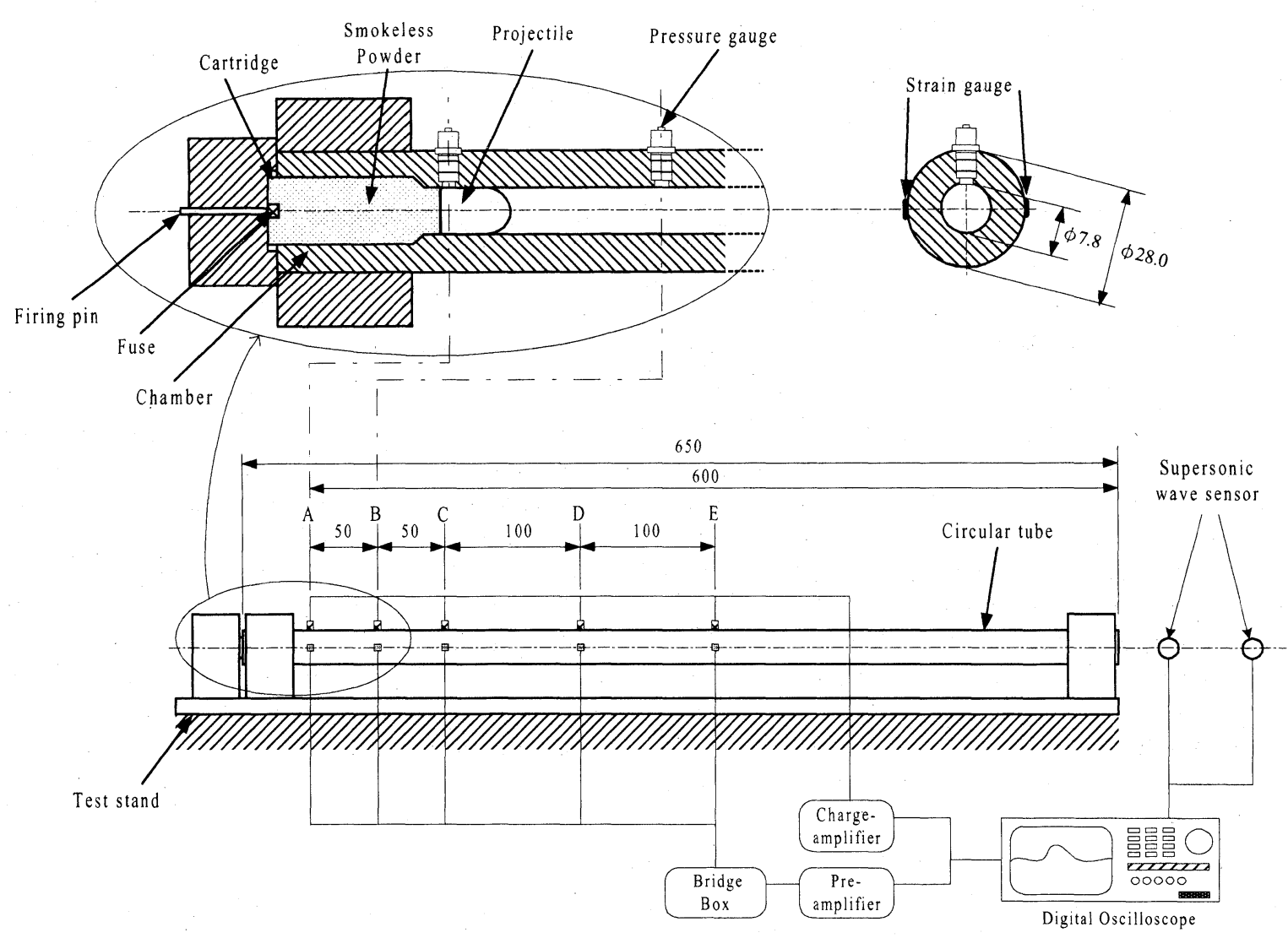

Fig. 1. Schematic diagram of experimental apparatus and measurement system.

\section{$2 \cdot 2$ 実験方法}

実験装置の概略を Fig. 1 に示す，使用した円管は，長 さ $650 \mathrm{~mm}$, 外径 $28.0 \mathrm{~mm}$, 内径 $7.8 \mathrm{~mm}$ の一様断面であ り，その一端には無煙火薬が装填された薬萊を挿入する ための薬室を設けた，実験装置では円管の両端を試験用 架台に固定した.

円管に飛翔体と薬萊を挿入した後，薬萊底部を固定し た。薬萊に取り付けられた雷管を点火し，薬萊内に装填 された約 $3 \mathrm{~g}$ の無煙火薬を発火させ，発生する燃焼ガス 圧により飛翔体を発射することで移動内圧を円管に負荷 した。燃焼ガスの温度は， $2000^{\circ} \mathrm{C}$ 以上 ${ }^{11)} に も$ 達するが， 本研究の変形挙動の時間では燃焼ガスによる熱の影響は 小さいとし，無視した。また，本論文では飛翔体の挙動 については取り扱わないが，尖頭形状で外径 $7.8 \mathrm{~mm}$ ，質 量約 $10 \mathrm{~g}$ の銅製の飛翔体を用いた。

移動内圧となる燃焼ガスの円管内への放出口である薬 萊の先端近傍 $\mathrm{A}$ 位置を計測上の原点とし，A位置および A 位置加ら 50mm (B), 100mm (C), 200mm (D), 300 $\mathrm{mm}(\mathrm{E})$ のそれぞれの位置に軸対称にひずみゲージ（共 和電業, KFG-3-120-D16-11）を貼付し，各位置の円周方 向ひずみおよび軸方向ひずみを計測した。 ひずみゲージ を貼付した同位置にピエゾ素子を用いた圧力センサ（キ スラー，6215）を円管内面に設置し，移動内圧を計測し た，検出されたひずみ信号は，ブリッジボックス，プリ アンプ (共和電業, CDA-700A) を介し, 同様に検出さ れた圧力信号はチャージアンプ（キスラー，5011A）を 介し，デジタルオシロスコープ（横河電機, DL716）に
記録された。ひずみ信号打よび圧力信号は，同時に 3 力 所のデータを記録した。さらに円管端部近傍に設置され た 2 個の超音波センサにより, 発射された飛翔体の通過 時間を計測し，円管からの飛翔体の離脱速度を求めた。

\section{3 実 験 結 果}

Fig. 2 に A，B，C 各位置での代表的な移動内圧の圧 力波形 $\mathrm{P}_{\mathrm{i}}$ の例を示す。なお， 5 回の繰り返し実験により， 得られた圧力波形の再現性を確認した。

$\mathrm{A}$ 位置の圧力波形 $\mathrm{P}-\mathrm{A}$ は, 無煙火薬の発火による燃焼 ガス圧の発生に伴い，急激にピーク圧力 (約 250MPa) まで上昇し, その後の内圧の移動に伴い圧力低下し, 立 ち上がりから約 $3 \mathrm{~ms}$ でほぼ圧力ゼロとなっている。

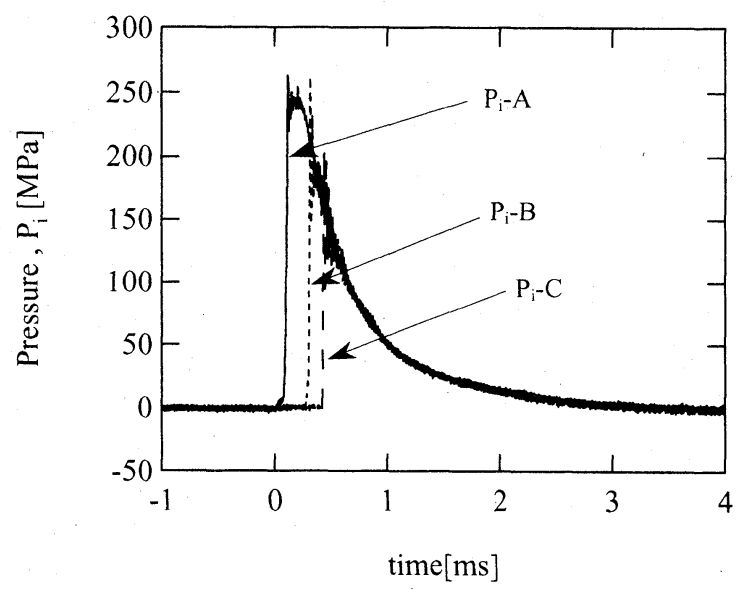

Fig. 2. Time histories of high-rate moving internal pressures measured at three locations $\mathrm{A}, \mathrm{B}$ and $\mathrm{C}$. 
$\mathrm{C}$ 各位置の圧力波形 $\mathrm{P}_{\mathrm{i}}-\mathrm{B}$ および $\mathrm{P}_{\mathrm{i}-\mathrm{C}}$ は，内圧の移動に より $\mathrm{P}_{\mathrm{i}}-\mathrm{A}$ からそれぞれ約 $250 \mu \mathrm{s}$ ，約 $380 \mu \mathrm{s}$ の時間遅れで

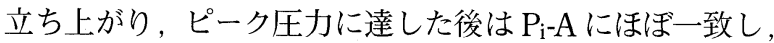
圧力ゼ口となっている。これらの結果から，円管各位置 における内圧は，内圧の発生源である薬室内部の圧力波 形および薬室と測定位置の間の距離に依存し，また，移 動内圧の到達以降, 薬室から飛翔体後部間の内圧は, ど の位置においてもほぼ一様になることがわかる。このよ うな移動内圧を受ける $\mathrm{A}, \mathrm{B}, \mathrm{C}$ 各位置の代表的な円周 方向ひずみ $\varepsilon_{\theta}$ および軸方向ひずみ $\varepsilon_{Z}$ の各波形を圧力波 形 $\mathrm{P}_{\mathrm{i}}$ と共に Fig. 3 に示す。なお各ひずみ波形は，圧力 波形と同様に繰り返し実験により再現性を確認した。

各位置において，圧力波形 $\mathrm{P}_{\mathrm{i}}$ は約 $3 \mathrm{~ms}$ でほぼ $0 \mathrm{MPa}$ となるが，ひずみ波形 $\varepsilon_{\theta}$ および $\varepsilon_{Z}$ は $0 \mu \varepsilon$ にならず，10 $\sim 25 \mu \varepsilon$ 程度の正の残留ひずみが見受けられる。これは， 飛翔体が円管を離脱する際に円管から放出される燃焼力゙ スがひずみゲージのリード線に温度影響を与え，零点が 正方向にドリフトしたものと推定される。この零点のド リフトは，飛翔体が円管から離脱してからの現象と考え られるため, 本研究の議論には影響無いと判断し，下記 に実験結果を考察する.

$\mathrm{A}$ 位置の円周方向ひずみ $\varepsilon_{\theta}-\mathrm{A}$ は，内圧 $\mathrm{P}_{\mathrm{i}}-\mathrm{A}$ とほぼ同 時に正（引張）方向に立ち上がり，その後 $\mathrm{P}_{\mathrm{i}} \mathrm{A}$ の圧力低 下に伴いひずみ量も低下している， B，C 各位置の円周 方向ひずみ $\varepsilon_{\theta}-\mathrm{B}$ および $\varepsilon_{\theta}-\mathrm{C}$ は，内压 $\mathrm{P}_{\mathrm{i}}-\mathrm{A}$ とほぼ同時 に，わずかに負（圧縮）方向を示し，その後移動内圧の 到達により正 (引張) 方向に立ち上がっている，移動内 圧の先頭波頭が通過後は，それぞれの内圧 $\mathrm{P}_{\mathrm{i}}-\mathrm{B}, \mathrm{P}_{\mathrm{i}}-\mathrm{C}$ の 低下に伴い，ひずみ量も低下している。

一方, $\mathrm{A}$ 位置の軸方向ひずみ $\varepsilon_{\theta}-\mathrm{A}$ は，内圧 $\mathrm{P}_{\mathrm{i}} \mathrm{A}$ 立立ち 上がりとほほ同時に，負（圧縮）方向から正（引張り） 方向に振動し，その後移動内圧の先導波頭が通過した後 は, 円周方向ひずみ $\varepsilon_{\theta}-\mathrm{A}$ に従い, 負 (圧縮) ひずみを示 している，B，C 各位置の軸方向ひずみ $\varepsilon_{z}-\mathrm{B}$ および $\varepsilon_{z}-\mathrm{C}$ は，内圧 $\mathrm{P}_{\mathrm{i}} \mathrm{-A}$ の立ち上がりとほぼ同時にわずかに正（引 張）方向を示し，各位置の内圧 $\mathrm{P}_{\mathrm{i}}-\mathrm{B}, \mathrm{P}_{\mathrm{i}}-\mathrm{C}$ の立ち上がり と共に，A 位置と同様に負 (圧縮) 方向から正 (引張) 方向に振動し，その後移動内圧の先導波頭が通過した後 は，それぞれの円周方向ひずみ $\varepsilon_{\theta}-\mathrm{B} ， \varepsilon_{\theta}-\mathrm{C}$ に従い，負 （圧縮）ひずみを示している。

$\mathrm{B}, \mathrm{C}$ 各位置で，内圧 $\mathrm{P}_{\mathrm{i}}-\mathrm{A}$ の立ち上がりとほぼ同時に 円周方向ひずみ $\varepsilon_{\theta}$ が負（圧縮）方向を示し，軸方向ひ ずみ $\varepsilon_{z}$ が正 (引張) 方向を示す挙動は, 薬室内での内圧 発生に伴う応力波が円管の軸方向に伝ぱした結果と考え られる。また，各位置の内圧 $\mathrm{P}_{\mathrm{i}}$ の立ち上がりとほぼ同時 に発生している軸方向ひずみ $\varepsilon_{z}$ の振動挙動は，移動内圧 先導波頭近傍の円管の変位挙動により生じたものと考え られる。上記の結果から推測される，移動内圧が B 位 置に到達した時の円管の変形挙動を模式的に Fig. 4 に 示す.

これらの円管の挙動を検証するため, 数值解析を行った.

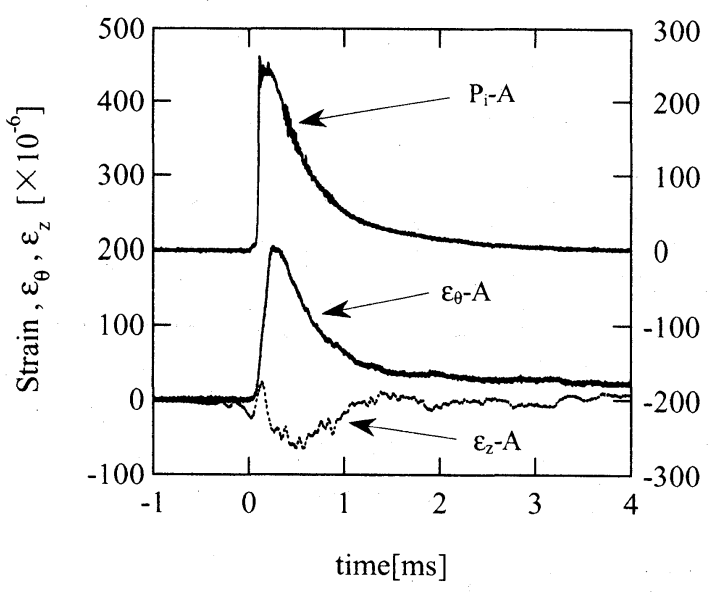

(a) at location $\mathrm{A}$

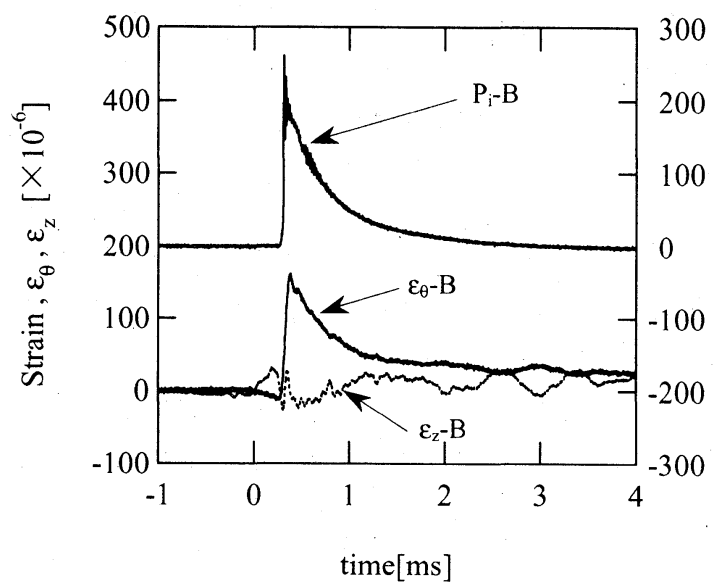

$\pi$
$\sum$
0
0
0
0
0
0

(b) at location $\mathrm{B}$

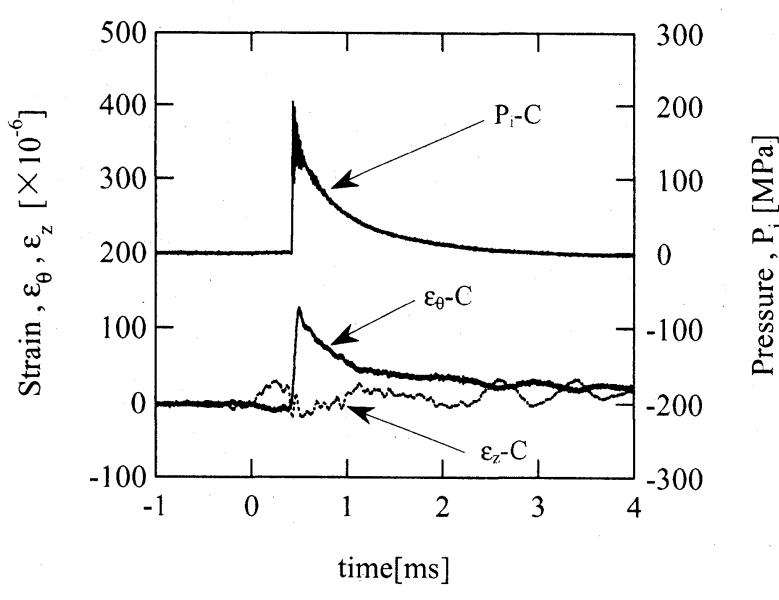

(c) at location $\mathrm{C}$

Fig. 3. Time histories of circumferential and axial strains and high-rate moving internal pressure on outer and inner surfaces of circular tube measured at three locations $\mathrm{A}, \mathrm{B}$ and $\mathrm{C}$. 


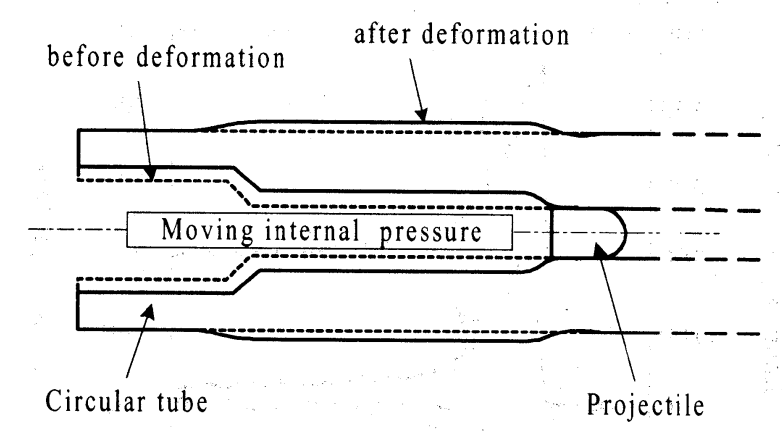

Fig. 4. Deformation of circular tube predicted from time histories of strains, Fig. 3.

\section{4 数 值 解 析}

\section{$4 \cdot 1$ 数值解析モデルおよび手法}

数值解析には, 沉用の陽解法有限要素法解析コードで あるLS-DYNA を用い，入力する材料データには，静的 引張試験により得られた Table I に示寸機械的性質を用 いた. 解析モデルは, 円管の軸対称性により Fig. 5 に示 す軸対称 2 次元モデルとし, 四角形シェル要素を用いて, $\mathrm{r}$ 方向に 4 分割, $Z$ 方向に 264 分割 (要素数：1056, 節 点数：1325）とした。実験状態を模擬するため, 薬室側 の円管端面の軸方向変位抢よび円管両端の半径方向変位 を拘束し，境界条件とした。

荷重条件設定のため, Fig. 6 に示す内圧の立ち上がり 時間差 (A-B 間 : $\Delta \mathrm{t}_{1}=$ 約 $250 \mu \mathrm{s}$, B-C間 : $\Delta \mathrm{t}_{2}=$ 約 $130 \mu \mathrm{s}, ）$ と各区間の距離から, 各区間に打ける移動内圧 の平均速度を算出し，それぞれの区間の中間地点におけ る移動内圧速度と仮定した，C-D 間，D-E 間においても 同様に移動内圧速度を算出した。 また, 円管からの飛翔 体の離脱速度を円管末端部での移動内圧速度と仮定した。 このように仮定した各位置の移動内圧速度から Fig. 7 に 示す近似曲線を求めた。

円管内面に負荷した圧力波形には，Fig. 2 に示した実 験から得られた圧力波形の近似波形として，ランプ状の 圧力波形を用いた. Fig. 7 の移動内圧速度の近似曲線か ら，A 位置から円管末端部までの円管各位置の移動内圧 到達時間を算出し，算出した移動内圧到達時間から各位 置の圧力波形を決定した。一例として，A，B，C各位置 に負荷した圧力波形 Pi-FEM F Fig. 8 に示す.

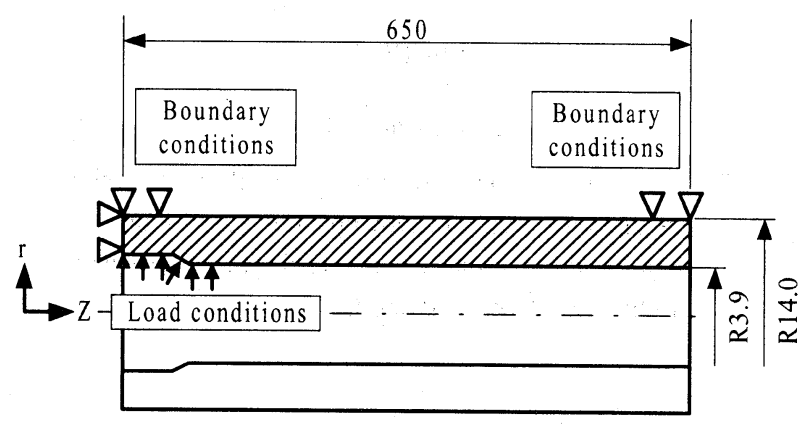

Fig. 5. Geometry and boundary and load conditions of FEM model.

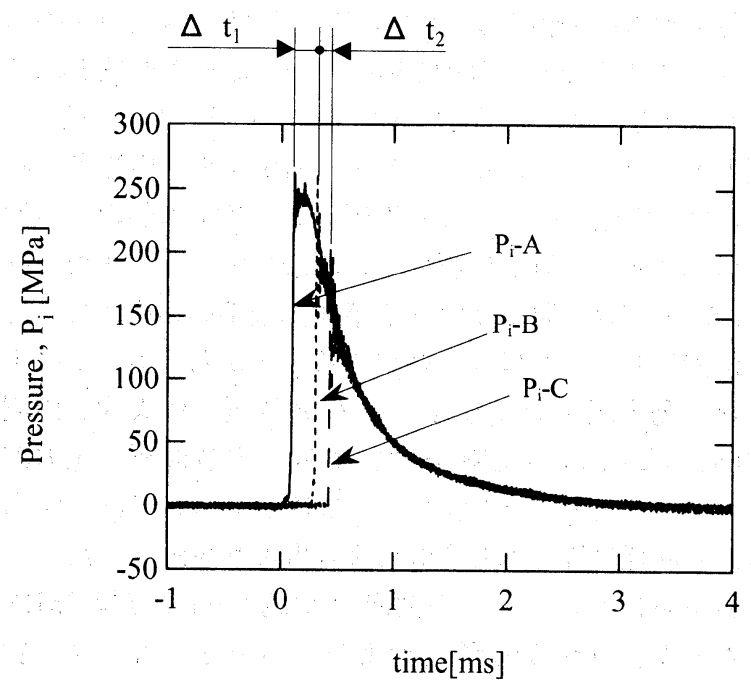

Fig. 6. Difference of rising time of moving internal pressure at three locations $\mathrm{A}, \mathrm{B}$ and $\mathrm{C}$ for calculation of moving internal pressure velocity.

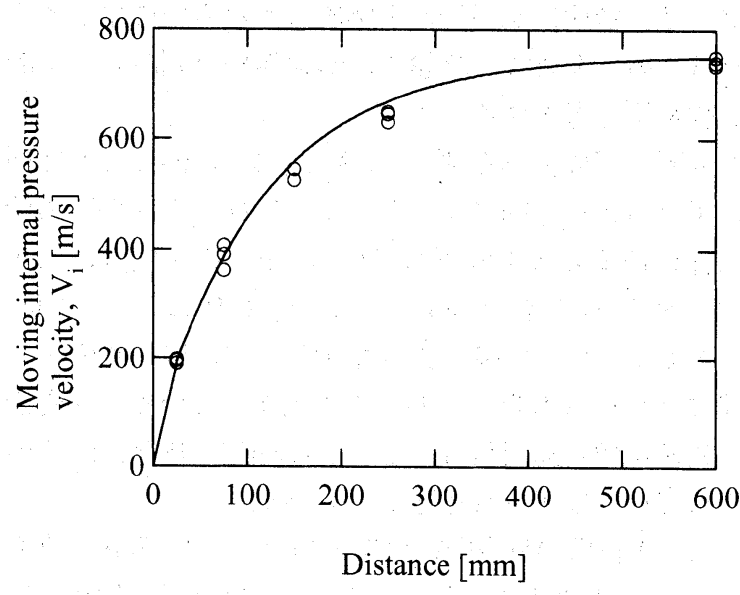

Fig. 7. Moving internal pressure velocity curve for analysis.

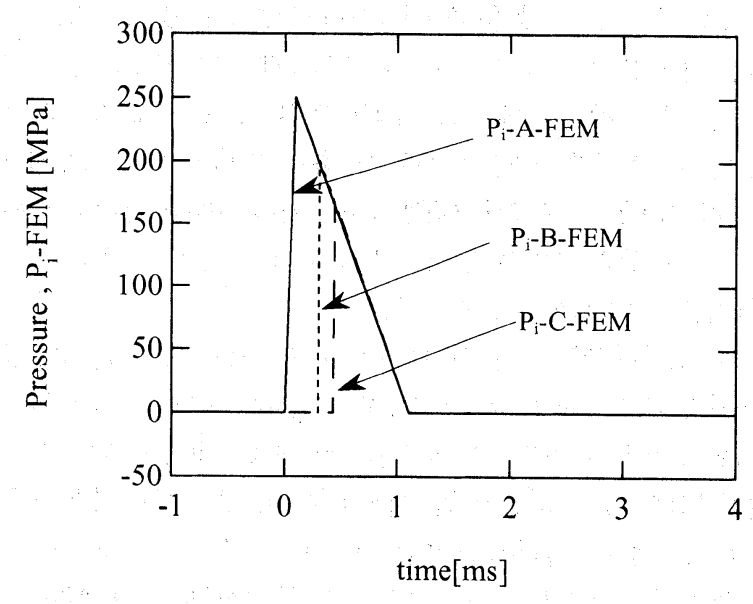

Fig. 8. Time histories of moving internal pressure for load conditions of analysis at three locations A, B and $\mathrm{C}$. 


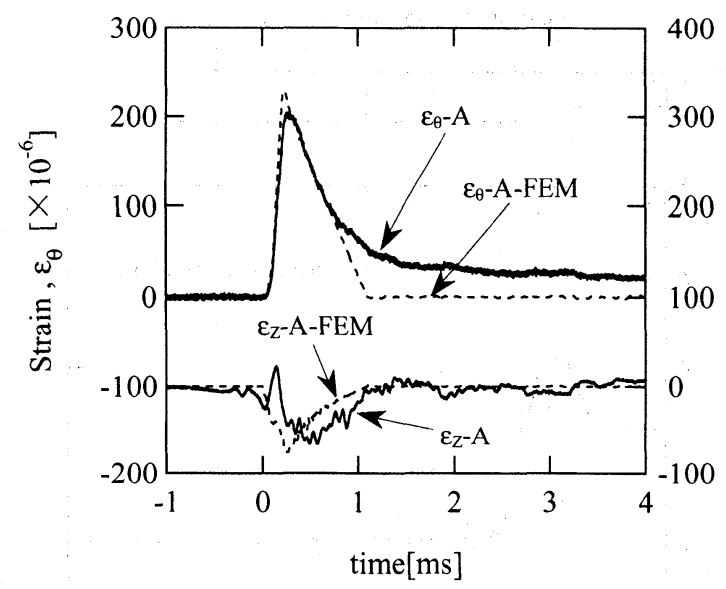

(a) at location $\mathrm{A}$

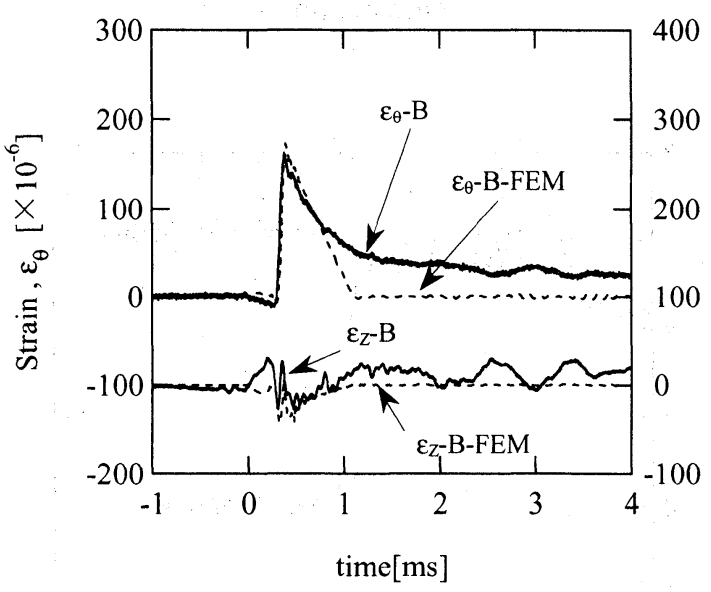

(b) at location $\mathrm{B}$

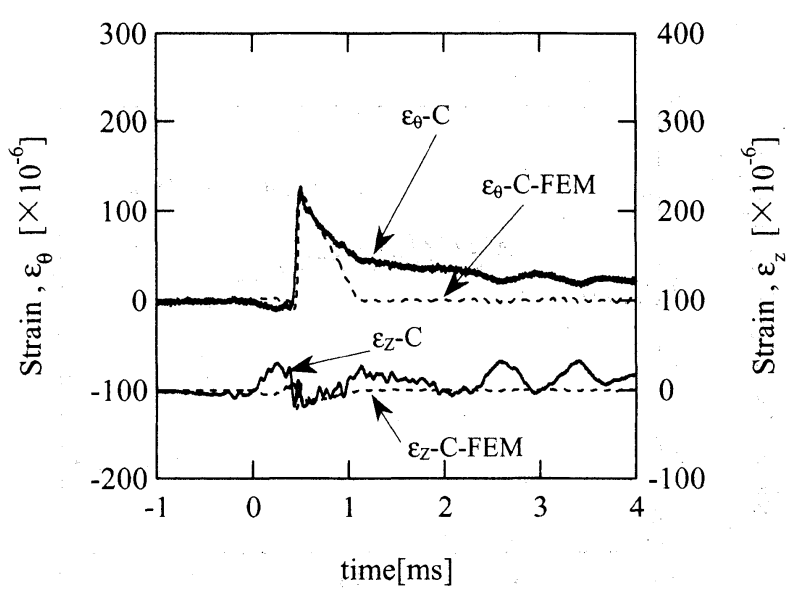

(c) at location $\mathrm{C}$

Fig. 9. Comparison between time histories of circumferential and axial strains measured and those calculated at three locations A, B and C.

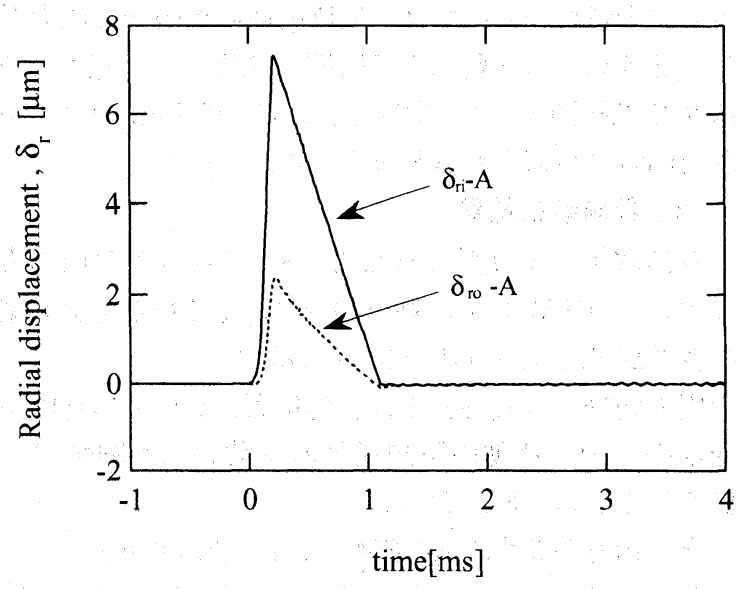

(a) at location $\mathrm{A}$

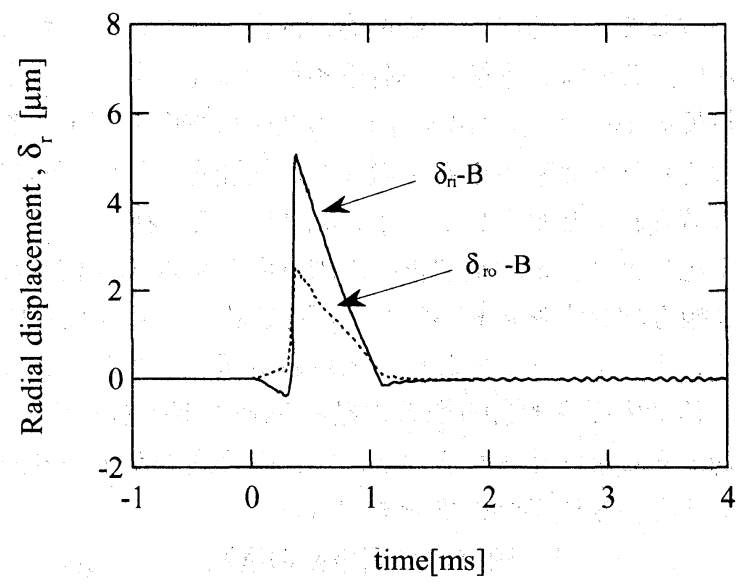

(b) at location $\mathrm{B}$

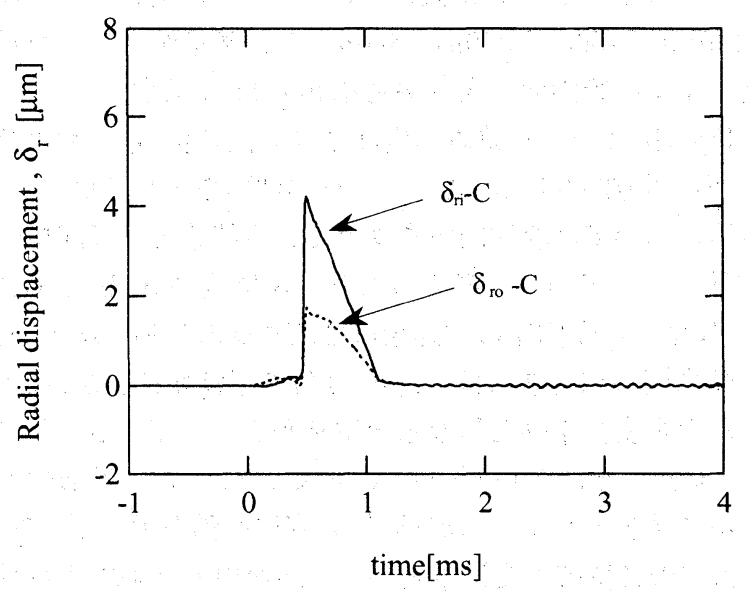

(c) at location $\mathrm{C}$

Fig. 10. Time histories of radial displacement in both of inner and outer surface of circular tube calculated at three locations A, B and C. 
さらに本解析においては, 無煙火薬の燃焼から圧力発 生による飛翔体の起動に至る時間を無視し, 薬室から A 位置までの範囲に，A 位置と同じ内圧 $\mathrm{P}_{\mathrm{i}}-\mathrm{A}-\mathrm{FEM}$ が，A 位置と同時に負荷されると仮定した。

\section{$4 \cdot 2$ 数値解析結果}

本数值解析により得られた A, B , C 各位置の円周方 向ひずみ $\varepsilon_{\theta}-\mathrm{FEM}$ および軸方向ひずみ $\varepsilon_{Z}$ FEM を実験結 果の各波形 $\varepsilon_{\theta}, \varepsilon_{Z}$ と共に Fig. 9 に示す.

円周方向ひずみ $\varepsilon_{\theta}$-FEM は, 各位置において移動内圧 到達前の挙動，移動内圧到達後の挙動共に実験結果 $\varepsilon_{\theta}$ を良くシミムレートしている。

一方, 軸方向ひずみ $\varepsilon_{z}-\mathrm{FEM}$ は, 各位置の内圧 $\mathrm{P}_{\mathrm{i}}$ の立 ち上がりとほぼ同時に発生している振動挙動や移動内圧 到達後の挙動については実験結果 $\varepsilon_{z}$ を良くシミュレート しているが，移動内圧到達前の挙動については定性的に は一致しているものの，定量的には良い一致が得られて いない，これは，本解析の荷重条件の設定において，本 来無煙火薬の燃焼に伴い，内圧の発生に時間差が生じる と考えられる薬室から A 位置までの範囲を, 内圧が同時 に負荷されると仮定したことが要因と考えられる。

上記により，本数值解析の円周方向ひずみ $\varepsilon_{\theta}-\mathrm{FEM}$ お よび軸方向ひずみ $\varepsilon_{Z} \mathrm{FEM}$ は, 実験結果 $\varepsilon_{\theta}, \varepsilon_{Z}$ を比較的 良くシミュレートしており, 本数值解析モデルおよび手 法が移動内圧を受ける円管の動的挙動を調べるために， 有効であると考えられる，そこで，円管内面打よび外面 の半径方向変位挙動の推測を試みた。

\section{5 円管内外面挙動の推測}

本数值解析により推測した A, B , C 各位置の内面半 径方向変位 $\delta_{\mathrm{ri}}$ および外面半径方向変位 $\delta_{\mathrm{ro}}$ の時間変位を Fig. 10 に, また, 各位置においてピーク圧力に達した時 刻 $($ time $=100 \mu \mathrm{s}, 350 \mu \mathrm{s}, 480 \mu \mathrm{s})$ の, 薬室から C 位置近 傍に至る円管内面の変位挙動を Fig. 11 に示す.

Fig. 10 より, A 位置の内面半径方向変位 $\delta_{\mathrm{ri}} \mathrm{A}$ および 外面半径方向変位 $\delta_{\mathrm{ro}} \mathrm{A}$ は，同様の波形を示しており， $\mathrm{A}$ 位置においては静的内圧を受けている状態とほぼ同様の 挙動を示していると考えられる. B 位置の $\delta_{\mathrm{r}-\mathrm{B}} \mathrm{B}$ および $\delta_{\mathrm{ro}}-\mathrm{B}$ は, 移動内圧の到達後はほぼ同様の挙動を示すが, 移動内圧の到達前には, $\delta_{\mathrm{ri}} \mathrm{B}$ は負の圧縮変位, $\delta_{\mathrm{ro}}$ - $\mathrm{B}$ は 正の引張変位挙動と異なる変位挙動を示していることが わかる.さらにC 位置の $\delta_{\mathrm{ri}} \mathrm{C}$ および $\delta_{\mathrm{ro}-} \mathrm{C}$ は, 波形はわ ずかに異なるものの，ほぼ同様の変位挙動を示している. これらの各位置の変位挙動から, 加速中の移動内圧を受 ける円管の内外面は, 内圧の発生による応力波の伝ぱ, 移動内圧速度の増大や移動内圧の圧力変動により, 各位 置において異なる挙動を示すことが推測される。また， 本研究の実験条件では, 円管の内径は $\mathrm{A}$ 位置で最大約 $15 \mu \mathrm{m}, \mathrm{B}$ 位置で最大約 $10 \mu \mathrm{m}, \mathrm{C}$ 位置で最大約 $8 \mu \mathrm{m}$ 程 度の膨張が生じることがわかる。飛翔体とのクリアラン スに影響すると考えられるこの内径の増大は，はめ合い 公差のすきまばめ公差程度であることが確認された。

Fig. 11より，移動内圧が負荷されている内面はもちろ ん，移動内圧が到達していない内面においても半径方向
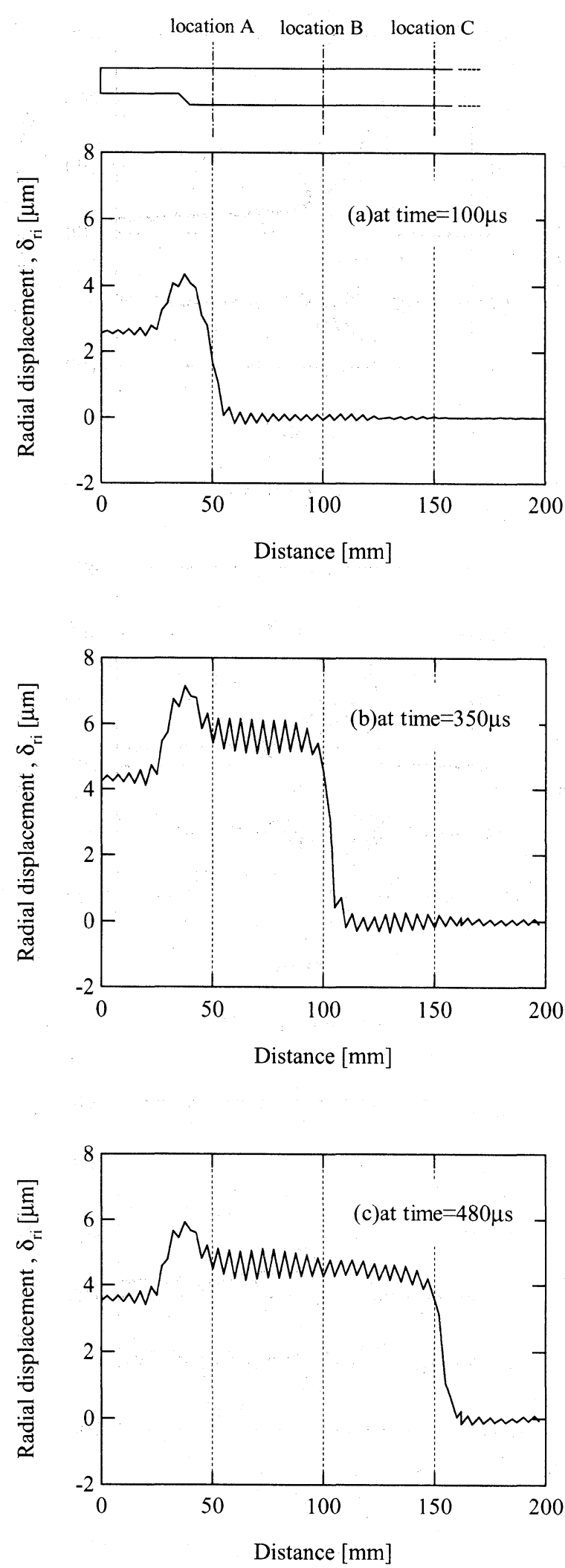

Fig. 11. Radial displacement distribution of inner surface of circular tube from chamber through location C calculated at $100 \mu$ s, $350 \mu$ s and $480 \mu$ s. 
変位に振動が生じていることがわかる. 応力波の伝ぱ速 度 $\mathrm{c}_{0}$ は $5192 \mathrm{~m} / \mathrm{s}$ であり, 例えば Fig. 11 (a) の time $=100$ $\mu \mathrm{s}$ の時刻には，応力波は既に円管軸方向に $500 \mathrm{~mm}$ 以上 伝ぱしている.このことから, 応力波が半径方向に伝ぱす ることにより，円管内外面で繰り返し反射が生じ，この 応力波の反射が円管半径方向に振動を生じさせているも のと判断される。 また， A, B, C 各位置における移動内 圧最前端近傍の円管内面の変位挙動は, 共に Fig. 4 に示 した模式図とほぼ同様の挙動を示すことが確かめられた。

\section{6 結}

言

円管に高速移動内圧を負荷する実験を行うと共に有限 要素法による数值解析を行い, 以下の知見を得た.

(1) 高速移動内圧を受ける円管内面の数力所で圧力波 形を計測し，また同時に円管外面の円周方向および軸方 向の応力波形を計測し, 再現性の良い実験結果を得た。

(2) 本数值解析結果は実験結果を比較的良くシミュ レートしており, 本数值解析モデルおよび手法の妥当性 が確認された。

(3) 本数值解析により, 加速中の高速移動内圧を受 ける円管の内外面挙動を推測することが出来た.

（4）本実験条件では, 内面の半径方向変位の増大は, はめ合い公差のすきまばめ公差程度であることが確認さ れた。

今後, 本解析手法により高速移動内圧を受ける円管の 詳細な挙動について検討を進め, 発射される飛翔体への 円管挙動の影響について解明していく予定である.
1）笠原次郎, 新井隆景, 赤井伸宇, 高沢光貴, 日本航空宇 宙学会北部支部 2001 年講演会論文集, 65（2001）。

2) 胡 習之, 可児弘毅, 第 7 回材料の衝撃問題シンポジウム 講演論文集, 115 (2002)。

3 ) 武藤康夫, 田村英樹, 平成 10 年度衝撃波シンポジウム講 演論文集, 409 (1999).

4 ) J. P. Jones and P. G. Bhutta, ASME Trans, J. Appl. Mech, 31, 105 (1964).

$5)$ S. Tang, J. Eng. Mech. Div, Proc. ASCE, 97 (1965).

6) H. Reismann, Solid Mechanics-Proc. 8th Midwestern Mechanics Conference, Part II , 2, 349 (1965).

7 ) T. E. Simkins, G. A. Pflegl and E. G. Stilson, Journal of Sound and Vibration 168, 549 (1993).

8) T. E. Simkins, Journal of Sound and Vibration 172, 145 (1994).

9 ) W. M. Beltman and J. E. Shepherd, Journal of Sound and Vibration 252, 617 (2002).

10) 山田敏郎, 可児弘毅, 生田耕治, 日本機械学会論文集, B-47, 450 (1981).

11）(社) 火薬学会編, “エネルギー物質ハンドブック”, p.67 (1999) 共立出版. 